\begin{tabular}{l|c|c}
\hline ISSN: 0001-5113 & ACTA ADRIAT., \\
AADRAY & $62(2): 183-198,2021$ & ORIGINAL SCIENTIFIC PAPER \\
\hline
\end{tabular}

\title{
Reproductive traits of the European hake, Merluccius merluccius (L. 1758), in the Adriatic Sea
}

\author{
Barbara ZORICA*, Igor ISAJLOVIĆ, Nedo VRGOČ, Vanja ČIKEŠ KEČ, Damir \\ MEDVEŠEK, Vedran VULETIN, Ivana RADONIĆ, Ratko CVITANIĆ, \\ Ivana LEPEN PLEIĆ and Marija ŠESTANOVIĆ
}

\author{
Institute of Oceanography and Fisheries, Šetalište Ivana Meštrovića 63, 21000 Split, Croatia \\ *Corresponding author, e-mail: zorica@izor.hr
}

Within this paper, reproduction traits of the Adriatic population European hake, Merluccius merluccius (Linnaeus, 1758), were investigated. Specimens of the target species were monthly collected $(N=1173)$ during 2019 along the eastern Adriatic Sea with commercial bottom trawlers. Overall, European hake total body length varied between 15.5 and $49.5 \mathrm{~cm}$ (mean $\pm S D=27.5 \pm 5.0$ $\mathrm{cm})$ and domination of females was noted in larger length classes $(T L>31.0 \mathrm{~cm})$. The sexual ratio of all specimens was $m / f=0.64$; male prevalence was established over the year, except during the spawning peaks (December, June) when the sex ratio was in favour of the females. According to European hake's maturity stages, gonad weights, gonadosomatic indexes and histological analysis of the gonad tissues, this species in Adriatic spawn twice in one year; the spawning period was from December to February, while second smaller signs of spawning were observed at the beginning of the summer, in June. 50\% of the European hake male and female specimens sexually matured at 20.7 $\mathrm{cm}$ and $22.4 \mathrm{~cm}$ of total length, respectively.

Key words: Sex ratio; Maturation; Spawning; Early life stages; Hake, Mediterranean

\section{INTRODUCTION}

Nowadays, according to the last and available stock assessments for the Mediterranean and the Black Sea the majority of exploited fish stocks are currently fished at biologically unsustainable levels (FAO, 2018). Those stock assessments, as well as the status of their stocks, were defined due to the values of the fishing mortality and the size of the spawning stocks (SSBspawning stock biomass) over the decades. One of the overexploited stocks that inhabit Adriatic Sea (Geographical sub-area (GSA): 17 and 18) is the stock of European hake, Merluccius merluccius (Linnaeus, 1758). This fish is considered as one of the major demersal commercial species, which official annual average catches from 2008 to 2018 in the Mediterranean as well as in the Adriatic were $18779.4 \pm 2583.4 \mathrm{t}$ and $856.6 \pm 135.2 \mathrm{t}$ (FAO, 2019), respectively.

Generally, European hake is a benthopelagic species, widely distributed in the north-eastern Atlantic (from Norway in the north to the Guinea Gulf in the south), Mediterranean as well as the Black Sea (CASEY and PERIERO, 1995; COHEN et al., 1990; FISCHER et al., 1987; MURUA, 
2010). As a demersal fish species, it occurs mostly between the depths of $70 \mathrm{~m}$ and $370 \mathrm{~m}$, although it can be found in both shallower (30 $\mathrm{m})$ and deeper $(1000 \mathrm{~m})$ waters (KORTA et al., 2015). In the Adriatic Sea, it is largely distributed along the whole area, except in the area north of the mouth of the Po river (FRATTINI and CASALI, 1998; JUKIĆ and ARNERI, 1984; PICCINETTI et al., 2012), while its bathymetric distribution goes from several meters in coastal areas to $800 \mathrm{~m}$ in the South Adriatic Pit (JUKIĆ-PELADIĆ et al., 1999; ŽUPANOVIĆ and JARDAS, 1987). Over the year, European hake individuals migrate within the Adriatic Sea either for food pursuit or for spawning. Namely, European hake juveniles migrations are driven by the search for food, hence during the spring they move towards the shallow areas, while during the winter months they are found in the area of Pomo/Jabuka Pit (PICCINETTI et al., 2012; VRGOČ et al., 2004) as this area in that period is known as an upwelling or nutrient rich area (ZAVATARELLI et al., 1998). European hake adults in the winter period migrate towards the area of Pomo/Jabuka Pit for spawning and it's first spawning peak appears (ŽUPANOVIĆ and JARDAS, 1987). Afterwards, in early spring, those specimens turn to shallower coastal areas where spawning invents continue but with lower intensity (UNGARO et al., 1993). The second peak of spawning occurs during the summer months and it also happens in the area of Pomo/Jabuka Pit (JUKIĆ and PICCINETTI, 1981; UNGARO et al., 1993; ŽUPANOVIĆ and JARDAS, 1987). This species is a multiple batch spawner, with length at first maturity oscillating within the total body length range of $20-33 \mathrm{~cm}$ and 21.5-43.0 cm in Adriatic (VRGOČ et al., 2004) and Mediterranean (CARBONARA et al., 2019), respectively. In the Adriatic Sea, European hakes are mainly caught with bottom trawlers and beam trawlers. Over the last two decades, European hake catches (landing and discard) and the values of assessed females spawning stock biomass in the whole Adriatic Sea (GSA 17 and GSA 18) fluctuated almost in the same manner; a decreasing trend within the mentioned period have been observed (STECF, 2019; 2020). Due to adverse European hake stock status, as well as status of Norway Lobster, the General Fisheries Commission for the Mediterranean (GFCM) establish fisheries restricted areas (FRA) in 2017 (FAO, 2017) that refers to Pomo/Jabuka Pit, an area known as the nursery and spawning area of mentioned species.

European hake reproductive parameters like sex ratio, size at sexual maturity, spawning period and fecundity were scarce and/or partly studied in the past (mostly in the second half of the last century - JUKIĆ and PICCINETTI 1981; ŽUPANOVIĆ and JARDAS 1986; UNGARO et al., 1993). Bearing in mind the present status of this stock as well as the fact that obvious climate-regiment shift did happened in Adriatic by the end of the last century (GRBEC et al., 2014) the main aim of this study was set. Namely, due to previous studies (DOMÍNGUEZ-PETIT et al., 2008; DOMÍNGUEZPETIT and SABORIDO-REY, 2010; MURUA, 2010) changes in reproduction traits might be expected due to observed changes in population biomass levels and environmental conditions in the study area. Hence, within this study, essential reproductive parameters of European hake are going to be improved and updated in order to improve existing management measures in the Adriatic Sea and in general.

\section{MATERIALS AND METHODS}

European hake specimens were monthly collected from commercial bottom trawlers, operating within the Croatian fishing ground (eastern Adriatic Sea, Fig. 1) from January to December 2019. Each month samples of investigated species were sampled either onboard $(\mathrm{N}=9)$ of commercial bottom trawl or on its landing place $(\mathrm{N}=17)$, put on ice and transported to the laboratory for the analysis.

A total of 1179 European hakes were analysed in the laboratory upon arrival. Total length $(\mathrm{TL}, \mathrm{cm})$ and weight $(\mathrm{W}, \mathrm{g})$ of each specimen were measured with the precision of $\pm 0.1 \mathrm{~cm}$ and $\pm 0.01 \mathrm{~g}$, respectively. Length frequency distribution of the collected European hakes was compared to the one obtained throughout scientific survey MEDITS (International bottom trawl survey in the Mediterranean) which 
was done in the same year to check for possible differences. The length-weight relationship was calculated separately for each sex by applying the exponential regression $W=a \mathrm{TL}^{b},(W=$ total fish weight in $\mathrm{g}$; TL = total length in $\mathrm{cm}$; $a=$ proportionality constant; and $b=$ allometric growth parameter). The hypotheses of isometrical growth, and abbreviation between male and female allometric growth parameter, were tested using a Student's t-test $(P<0.05)$.

Sex and gonad maturity stages were assessed macroscopically according to MEDITS protocol. Used maturity scale has 8 maturity stages and its description is taken from MEDITS Handbook (AAVV, 2017) and given in Table 1. The overall sex ratio (males: females), sex ratio by size intervals $(1.0 \mathrm{~cm})$ and sex ratio by month were obtained by dividing the number of males by the total number of the individuals.

Over the study period, each month, gonads of 10 adult female individuals were taken for histological analysis. Histology was carried out not only to confirm macroscopically determined stages of gonads but also to endorse European hake as indetermined batch spawner. Gonads were fixed in $4 \%$ formaldehyde solution. Afterwards, the gonads were dehydrated in alcohol and embedded in paraffin wax. Longitudinal or cross sections were made with a microtome. The section thickness was $10 \mu \mathrm{m}$. Sections were stained with haematoxylin and eosin. Obtained histological slides of gonads were examined under a stereomicroscope (Zeiss Discovery. V12; magnification 150x). Oocytes were classified according to (BROWN-PETERSON et al., 2011)

Each histological slide of female gonad tissue was photographed by a camera coupled to Zeiss binocular microscope and a PC. By image analysis and processing that was carried out using Zeisse-software the maximum and minimum diameters of oocytes in different development stages were measured and then were averaged to obtain the mean size of each oocyte. Microscopic maturity staging of ovaries was done according to CARBONARA et al. (2019) who provided European hakes oocites development for each macroscopical maturity stage in the MEDITS scale (Table 1).

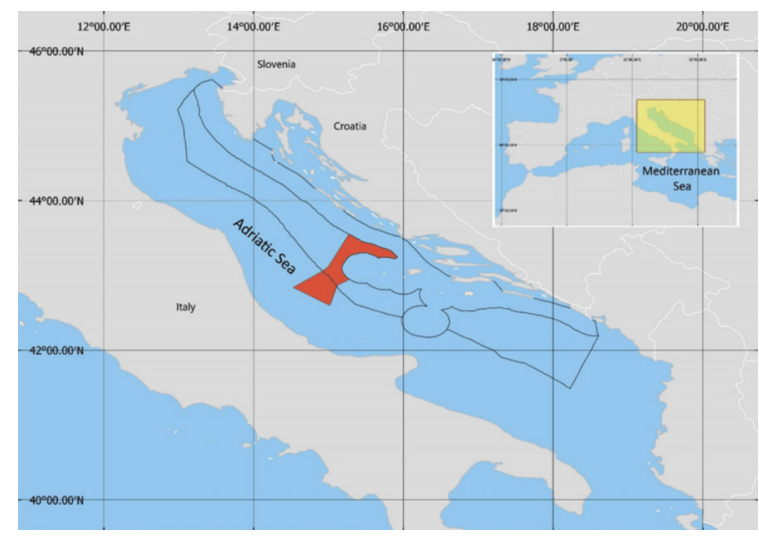

Fig. 1. Map of the Adriatic Sea showing the study arealines are surrounding Croatian fishing ground while red area refers to FRA Jabuka/Pomo pit

The spawning seasonality of the European hake was described based on the data of the monthly changes in gonadosomatic index (GSI: the proportion of monthly gonad weight $(\mathrm{Wg}$, $\mathrm{g}$ ) in the total body weight (W, g)) and the fluctuations of maturity stages. GSI values by each maturity stage were compared and statistically analysed.

For the determination of the lengths at maturity $\left(\mathrm{L}_{50}\right.$, the length at which $50 \%$ of the individuals in population are mature) only specimens exclusively collected during spawning were used. Length at maturity was determined by proportion of spawning fish (gonads staged as $2 \mathrm{~b}, 2 \mathrm{c}, 3,4 \mathrm{a}$ and $4 \mathrm{~b}$ ) in each $1 \mathrm{~cm}$ size class, fit into a logistic model:

$$
P(x)=\frac{a}{1+e^{b+c x}}
$$

where $P$ is the percentage of mature fish at length $x$ and $a, b$ and $c$ are constants.

All statistical analyses were performed with SPSS 5.5 software package and a level of significance of $\alpha=0.05$ was accepted.

\section{RESULTS}

Among all European hakes, collected along the eastern side of the Adriatic Sea from January till December 2019, 749 were males, 424 were females and for 6 individuals' sex was not determined due to the poor condition of their 
Table 1. Description of macroscopic maturity scale provided by MEDITS protocol (AAVV, 2017) along with the female microscopic appearance provided for each MEDITS maturity stage given by CARBONARA et al. (2019)

\begin{tabular}{|c|c|c|c|}
\hline Stage & Maturation state & Macroscopic characteristics & Microscopic characteristics \\
\hline 0 & UNDETERMINED & $\begin{array}{l}\text { Sex not distinguished by naked eye. Gonads very } \\
\text { small and translucid, almost transparent. Sex } \\
\text { undetermined. }\end{array}$ & \\
\hline 1 & IMMATURE-VIRGIN & $\begin{array}{l}\text { Small pinkish and translucent ovary shorter than } \\
1 / 3 \text { of the body cavity; eggs not visible by naked } \\
\text { eye. Thin and whitish testis shorter than } 1 / 3 \text { of the } \\
\text { body cavity. }\end{array}$ & $\begin{array}{l}\text { Only OO and PG through } \\
\text { the perinuclear stage are } \\
\text { present. The ovarian wall is } \\
\text { thin and little space between } \\
\text { oocytes are observed. }\end{array}$ \\
\hline $2 \mathrm{a}$ & $\begin{array}{l}\text { VIRGIN- } \\
\text { DEVELOPING }\end{array}$ & $\begin{array}{l}\text { Small pinkish/reddish ovary shorter than } 1 / 2 \text { of e } \\
\text { body cavity; eggs not visible by naked eye. Thin } \\
\text { whitish testis shorter than } 1 / 2 \text { of the body cavity. }\end{array}$ & \\
\hline $2 b$ & RECOVERING & $\begin{array}{l}\text { Pinkish-reddish/ reddish-orange and translucent } \\
\text { ovary long about } 1 / 2 \text { of the body cavity. Blood } \\
\text { vessels visible; eggs not visible by naked eye. } \\
\text { Whitish/pinkish testis, more or less symmetrical, } \\
\text { long about } 1 / 2 \text { of the body cavity. }\end{array}$ & $\begin{array}{l}\text { Only PG and CA oocytes are } \\
\text { visible. }\end{array}$ \\
\hline $2 \mathrm{c}$ & MATURING & $\begin{array}{l}\text { Ovary pinkish-yellow in colour with granular } \\
\text { appearance, long about } 2 / 3 \text { of the body cavity. Eggs } \\
\text { are visible by naked eye trough the ovary tunica, } \\
\text { which is not yet translucent. Under light pressure } \\
\text { eggs are not expelled. Whitish to creamy testis long } \\
\text { about } 2 / 3 \text { of the body cavity. Under light pressure } \\
\text { sperm is not expelled. }\end{array}$ & $\begin{array}{l}\text { PG, CA, Vtg1 and Vtg2 } \\
\text { oocytes are observed. No } \\
\text { evidence of POFs. Some } \\
\text { atresia can be present. }\end{array}$ \\
\hline 3 & MATURE/SPAWNER & $\begin{array}{l}\text { Ovary orange-pink in colour, with conspicuous } \\
\text { superficial blood vessels, long from } 2 / 3 \text { to full } \\
\text { length of the body cavity. Large transparent, ripe } \\
\text { eggs are clear visible and could be expelled under } \\
\text { light pressure. In more advanced conditions, eggs } \\
\text { escape freely. Whitish-creamy soft testis long } \\
\text { from } 2 / 3 \text { to full length of the body cavity. Under } \\
\text { light pressure, sperm could be expelled. In more } \\
\text { advanced conditions, sperm } \\
\text { escapes freely. }\end{array}$ & $\begin{array}{l}\text { All stages present: PG, CA, } \\
\text { Vtg1, Vtg2, Vtg3 oocytes } \\
\text { and/or oocytes undergoing } \\
\text { hydration (GVM, GVBD, } \\
\text { HO). If spawning is already } \\
\text { started, } \\
\text { POFs are observed. Atresia } \\
\text { (AO) of vitellogenic and/ } \\
\text { or hydrated oocytes may be } \\
\text { present. }\end{array}$ \\
\hline $4 \mathrm{a}$ & SPENT & $\begin{array}{l}\text { Reddish ovary shrunken to about } 1 / 2 \text { length of } \\
\text { the body cavity. Flaccid ovary walls; ovary may } \\
\text { contain remnants of disintegrating opaque and/ } \\
\text { or translucent eggs. Bloodshot and flabby testis } \\
\text { shrunken to about } 1 / 2 \text { length of the body. }\end{array}$ & $\begin{array}{l}\text { Atresia of vitellogenic } \\
\text { oocytes and POFs can be } \\
\text { visible. PG and CA present. }\end{array}$ \\
\hline $4 \mathrm{~b}$ & RESTING & $\begin{array}{l}\text { Pinkish and translucent ovary long about } 1 / 3 \text { of } \\
\text { the body cavity. Eggs not visible by naked eye. } \\
\text { Whitish/pinkish testis, more or less symmetrical, } \\
\text { long about } 1 / 3 \text { of the body cavity. }\end{array}$ & $\begin{array}{l}\text { Only OO and PG } \\
\text { oocytes (sometimes with } \\
\text { circumnuclear oil droplets) } \\
\text { are observed. The ovarian } \\
\text { wall is thicker and there is } \\
\text { more space, } \\
\text { interstitial tissue and } \\
\text { capillaries around PG } \\
\text { oocytes than those observed } \\
\text { at the immature stage. }\end{array}$ \\
\hline
\end{tabular}


gonads, hence, they were excluded from further analysis. Minimum and maximum values of male total body length were $15.5 \mathrm{~cm}$ and $42.0 \mathrm{~cm}$, respectively (Fig. 2; Table 2). Mean monthly total body lengths of European hake males varied over the investigated period and the highest values were recorded during the summer months (June - September, Table 2), while on the yearly basis the mean total body length of all male specimens was $26.4 \pm 4.1 \mathrm{~cm}$. In general, European hake females were larger than males showing total body length range and mean yearly value of $16.5-49.5 \mathrm{~cm}$ (Fig. 2; Table 2) and $29.3 \pm 6.8 \mathrm{~cm}$, respectively. As well as in males, somewhat larger females were also caught during the warmer part of the year (April - September). European hake male and female length frequencies within the whole investigated period were significantly different (Kolmogorov-Smirnov Test, $P<0.001$ ); all specimens with TL $>42.0 \mathrm{~cm}$ were exclusively female. Furthermore, the length distribution of fish species collected within this study $(15.5 \mathrm{~cm}$ $<$ TL $<49.5 \mathrm{~cm}$; January - December, 2019) was significantly different (Kolmogorov-Smirnov Test, $P<0.001$ ) from European hake length distribution obtained throughout MEDITS survey that happened in the same year and area (10.0 $\mathrm{cm}<\mathrm{TL}<78 \mathrm{~cm}$; Croatian fishing ground, June - July 2019; (STECF, 2020)). As far as total body weight, in both sexes, it followed the observed length trends. The total body weight range for male and female European hakes fit within the values of $23.18-507.20 \mathrm{~g}$ and $27.00-753.98$ g, respectively (Table 2). Overall, the mean total body weight for male was $130.76 \pm 62.20 \mathrm{~g}$, while for females it was slightly higher with the value of $187.16 \pm 108.06 \mathrm{~g}$.

The growth of the European hake males $\left(\mathrm{W}=0.0049 \mathrm{TL}^{3.0892} ; \mathrm{r}^{2}=0.958\right.$; Fig. 3A), as well as females $\left(\mathrm{W}=0.0061 \mathrm{TL}^{3.0275} ; \mathrm{r}^{2}=0.961\right.$; Fig. $3 \mathrm{~B})$, proved to be isometrical as the values of parameter $b$ did not statistically differ from 3 (Student's t-test $(P<0.05))$. Therefore, the hypothesis of isometric growth for this species was accepted for both sexes, despite that monthly mean values of allometrical coefficients varied within the investigated period for both sexes. Namely, the allometrical coefficient of males ranged from 2.729 (September) to 3.114 (December), while for females its range was slightly wider and goes from 2.612 (April) to 3.460 (December).

During the investigated period European hake sex ratio was statistically significant in favour of males $\left(m / f=0.64 ; \chi^{2}=56.54\right.$, d.f $\left.=1, P<0.05\right)$. The sex ratio of studied species varied with size since males were represented at smaller length sizes, while females were dominant at larger length classes (Fig. 4). Namely, in the length classes below $31.0 \mathrm{~cm}$, the domination of males was obvious with its mean values of $m / f=0.73$. A greater proportion of females was observed in higher length classes, precisely from total body length class of $31.0 \mathrm{~cm}$ onwards. Monthly variations of sex ratio, which are shown in Fig. 5, revealed the prevalence of females only in two months (June and December) of the year. Afterwards, the sex ratio was dominated by the males.

Histology of the collected ovaries $(\mathrm{N}=87)$ reveals the differences between macro- and microscopic staging. Maturity stages $2 \mathrm{a}$ and $4 \mathrm{a}$ were macroscopically correctly identified (Table 3). Macroscopic maturity stage $2 b$, if it was incorrectly determined, was usually replaced by the maturity stage $4 b$. Maturity stage $2 c$ and 3 were mostly replaced by maturity stage $2 b$ and $4 \mathrm{a}$, respectively. In the ovaries of the specimens that were prepared to spawn or just started to spawn histological analysis reveals the presence of almost all oocyte stages (PG, CA, Vtg1,

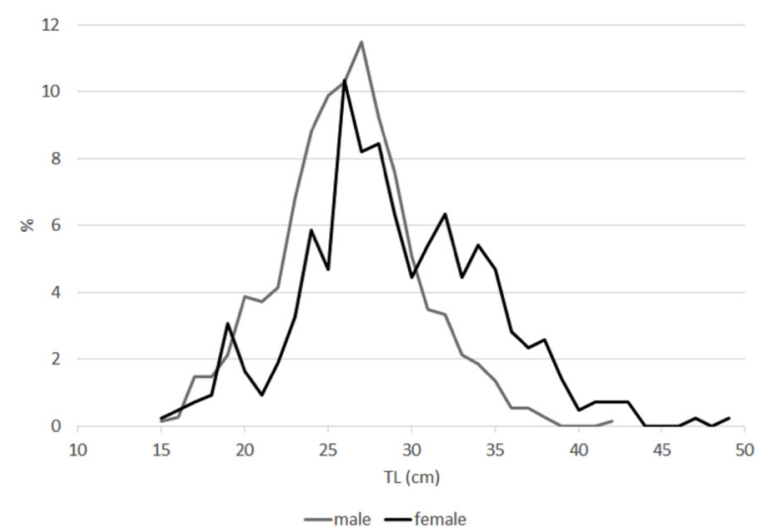

Fig. 2. Total length (TL, cm) frequency distribution of European hake male and female specimens collected with commercial bottom trawler along the eastern Adriatic Sea, January - December 2019 
Table 2. Overview of the monthly collected male and female European hake specimens along the eastern side of the Adriatic Sea from January to December,2019; regarding its number (N), total body lengths (TL, cm), total body weights (W, $g)$, gonad weights $(W g, g)$ as well as its monthly mean values with their standard deviations $(S D)$ values

\begin{tabular}{|c|c|c|c|c|c|c|c|}
\hline Month & $\mathbf{N}$ & $\begin{array}{c}\text { Range } \\
\text { TL (cm) }\end{array}$ & $\begin{array}{c}\text { Mean } \\
\mathrm{TL}(\mathrm{cm}) \pm \mathrm{SD}\end{array}$ & $\begin{array}{c}\text { Range } \\
\text { W(g) }\end{array}$ & $\begin{array}{c}\text { Mean } \\
\mathbf{W}(\mathrm{g}) \pm \mathrm{SD}\end{array}$ & $\begin{array}{l}\text { Range } \\
\text { Wg (g) }\end{array}$ & $\begin{array}{c}\text { Mean } \\
\mathrm{Wg}(\mathrm{g}) \pm \mathrm{SD}\end{array}$ \\
\hline \multicolumn{8}{|l|}{ Males } \\
\hline January & 109 & $15.5-38.5$ & $23.8 \pm 5.2$ & $23.18-343.80$ & $98.63 \pm 70.17$ & $0.02-4.87$ & $0.59 \pm 0.75$ \\
\hline February & 69 & $17.0-36.5$ & $25.5 \pm 4.4$ & $28.66-367.50$ & $114.27 \pm 68.86$ & $0.04-4.56$ & $1.12 \pm 1.11$ \\
\hline March & 110 & $17.0-35.5$ & $25.6 \pm 3.9$ & $28.67-301.90$ & $116.67 \pm 53.90$ & $0.05-3.59$ & $0.79 \pm 0.6$ \\
\hline April & 38 & $23.0-35.0$ & $28.3 \pm 2.9$ & $70.81-260.08$ & $148.45 \pm 44.53$ & $0.02-1.42$ & $0.67 \pm 0.38$ \\
\hline May & 70 & $21.0-36.0$ & $26.5 \pm 2.9$ & $63.90-313.50$ & $126.80 \pm 45.67$ & $0.12-1.97$ & $0.60 \pm 0.43$ \\
\hline June & 19 & $26.0-37.0$ & $30.8 \pm 2.9$ & $118.70-340.72$ & $199.24 \pm 59.50$ & $0.11-1.77$ & $0.68 \pm 0.50$ \\
\hline July & 59 & $21.5-33.5$ & $27.7 \pm 3.2$ & $72.81-278.95$ & $151.12 \pm 51.32$ & $0.05-1.74$ & $0.49 \pm 0.4$ \\
\hline August & 43 & $25.0-38.0$ & $28.5 \pm 3.2$ & $108.72-387.70$ & $163.85 \pm 66.50$ & $0.17-1.83$ & $0.82 \pm 0.4 \mathrm{C}$ \\
\hline September & 39 & $26.5-42.0$ & $29.5 \pm 2.8$ & $117.73-507.20$ & $175.80 \pm 62.39$ & $0.28-2.12$ & $0.79 \pm 0.46$ \\
\hline October & 88 & $20.0-37.5$ & $26.9 \pm 3.2$ & $49.56-377.21$ & $140.84 \pm 54.77$ & $0.07-2.70$ & $0.55 \pm 0.3$ \\
\hline November & 75 & $17.0-35.0$ & $26.1 \pm 3.9$ & $29.44-278.62$ & $123.79 \pm 54.87$ & $0.03-2.92$ & $0.55 \pm 0.5$ \\
\hline December & 30 & $23.0-29.0$ & $25.7 \pm 1.6$ & $87.15-181.99$ & $122.58 \pm 24.75$ & $0.11-3.65$ & $1.10 \pm 0.79$ \\
\hline \multicolumn{8}{|l|}{ Females } \\
\hline January & 39 & $16.5-42.0$ & $24.4 \pm 6.9$ & $27.00-473.15$ & $120.50 \pm 109.28$ & $0.04-16.28$ & $1.61 \pm 3.46$ \\
\hline February & 13 & $19.0-37.0$ & $28.1 \pm 5.9$ & $35.11-329.49$ & $156.08 \pm 90.57$ & $0.06-10.23$ & $2.97 \pm 2.93$ \\
\hline March & 35 & $19.5-39.0$ & $27.7 \pm 4.5$ & $39.26-373.03$ & $154.26 \pm 70.96$ & $0.04-14.11$ & $2.08 \pm 3.53$ \\
\hline April & 38 & $25.5-49.5$ & $31.3 \pm 5.5$ & $106.61-753.98$ & $215.08 \pm 122.95$ & $0.31-6.24$ & $1.08 \pm 1.0$ \\
\hline May & 50 & $21.0-43.5$ & $31.1 \pm 5.5$ & $56.80-635.27$ & $220.01 \pm 114.53$ & $0.14-2.84$ & $0.86 \pm 0.6$ \\
\hline June & 21 & $26.5-39.0$ & $32.7 \pm 4.1$ & $135.68-391.70$ & $243.25 \pm 82.22$ & $0.21-1.56$ & $0.78 \pm 0.33$ \\
\hline July & 48 & $24.0-41.5$ & $30.8 \pm 4.1$ & $88.30-458.18$ & $212.35 \pm 85.77$ & $0.14-9.67$ & $1.40 \pm 2.14$ \\
\hline August & 21 & $25.0-37.5$ & $32.4 \pm 3.8$ & $111.66-377.30$ & $239.25 \pm 75.66$ & $0.13-1.66$ & $0.65 \pm 0.3$ \\
\hline September & 31 & $26.5-43.5$ & $33.1 \pm 5.4$ & $126.55-489.10$ & $252.25 \pm 108.92$ & $0.25-6.17$ & $1.37 \pm 1.07$ \\
\hline October & 54 & $22.0-47.0$ & $28.5 \pm 4.7$ & $57.06-643.12$ & $168.44 \pm 96.99$ & $0.18-11.46$ & $1.72 \pm 2.50$ \\
\hline November & 34 & $18.0-35.0$ & $26.2 \pm 3.9$ & $35.57-251.95$ & $121.20 \pm 52.05$ & $0.04-2.57$ & $0.58 \pm 0.5$ \\
\hline December & 40 & $23.0-35.0$ & $27.7 \pm 3.3$ & $87.15-344.60$ & $167.39 \pm 75.22$ & $0.13-27.44$ & $6.08 \pm 7.85$ \\
\hline
\end{tabular}

Vtg2, Vtg3, AO; Fig. 6). Throughout histological analysis, diameter of 11311 oocytes $(\mathrm{N}=60)$ were measured with the lowest and highest values obtained at $12.69 \mu \mathrm{m}(\mathrm{PG})$ and 596.0 $\mu \mathrm{m}$ (AO), respectively. Diameter ranges of all observed and measured oocyte stages are shown in Fig. 7.

According to obtained values of the monthly percentage composition of gonad maturity stages and the mean monthly gonadosomatic indices, a trend in spawning seasonality was noted (Table 2, Fig. 8). The gonads in maturity stages defined as maturing (2c), mature (3) and spent (4a) were present almost during the whole year, their higher percentages were noted from December to March. The slight increase of spent specimens was also noted in summer month, precisely in August. The most abundant maturity stage over the year was $2 b$ - gonads in the stage of recovering. Regarding the values of gonadosomatic index it was noted that female had much higher values of this parameter than males. The highest values of gonadosomatic index were reached during the winter months (December - February), particularly in December (male: GSI $=0.915 ; \mathrm{Wg}=1.10 \mathrm{~g}$; female: $\mathrm{GSI}=2.779 ; \mathrm{Wg}=6.08 \mathrm{~g}$ ). Whereupon, values of the gonadosomatic index with slight oscillation decreased till the end of the summer (Fig. 8). Slightly increase of GSI values were observed in June for males and July for females. The lowest values of gonadosomatic index were reached in 

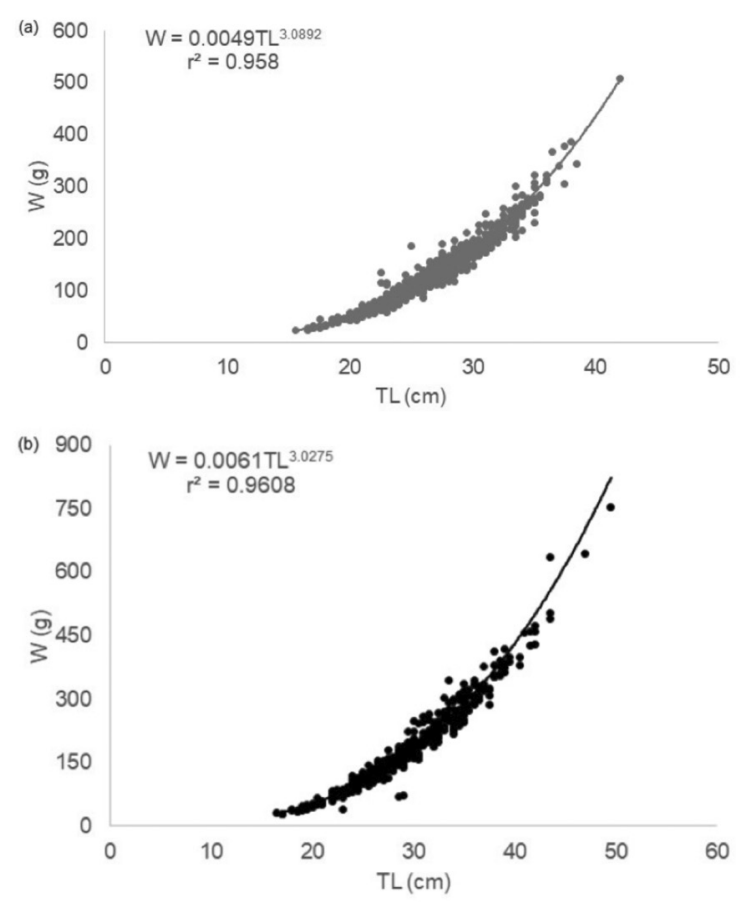

Fig. 3. The length (TL) - weight $(W)$ relationship of male (a) and female (b) European hake specimens caught with commercial bottom trawlers along the eastern Adriatic Sea, January - December 2019

July and August for male and female specimens, respectively. By the beginning of the autumn, the values of the two reproductive parameters started to increase. Calculation of the GSI values for each maturity stages pointed out that the highest and the lowest values were obtained for the gonads which were determined as spawning or just spawn and gonads in the resting/recovering stage (Fig. 9), respectively. This was also confirmed by the statistically analysis (KrusakWallis ANOVA, $\mathrm{H}=453.038$, d.f. $=6 ; P<0.05$ ), while Post-hoc test indicated that only GSI values of the resting and recovering stages were

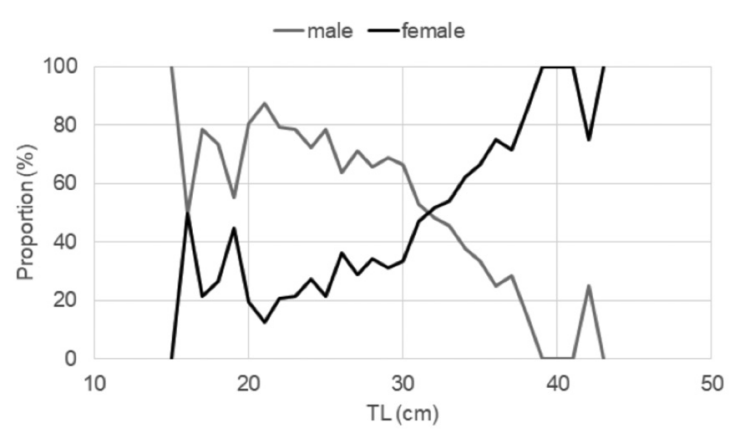

Fig. 4. Proportion of the sex ratio by length size classes of European hake specimens caught with commercial bottom trawlers along the eastern side of Adriatic Sea, January - December 2019.

not statistically significant difference (Fisher LSD Post-hoc test; $P>0.05$ ), while among the other stages difference in their GSI values were pronounced.

During the main spawning season (December - February, Fig. 8) the smallest mature European hake male had a total body length of $17.5 \mathrm{~cm}$, while the smallest mature females showed highest total body length of $22.5 \mathrm{~cm}$. According to the proportion of matured specimens within the spawning season estimated total body length at which $50 \%$ of males and females were matured was $20.74 \mathrm{~cm}(a=1.01$; $\left.b=13.32 ; c=-0.64 ; r^{2}=0.966\right)$ and $22.38 \mathrm{~cm}$ $\left(a=1.01 ; b=26.70 ; c=-1.19 ; r^{2}=0.992\right)$ (Fig. 10), respectively.

\section{DISCUSSION}

In this study length frequency distribution of both sexes was unimodal with the peaks reached at the length classes of $24.0 \mathrm{~cm}$ for males and $26.0 \mathrm{~cm}$ for females (Fig. 2). Length range of

Table 3. Comparison of the maturity stages determined macroscopically and microscopically for the same gonad

\begin{tabular}{ccccccccc}
\cline { 5 - 8 } Microscopic identification & & \multicolumn{6}{c}{ Macroscopic identification (\%) } \\
\cline { 5 - 9 } & $\mathrm{N}$ & $2 \mathrm{a}$ & $2 \mathrm{~b}$ & $2 \mathrm{c}$ & 3 & $4 \mathrm{a}$ & $4 \mathrm{~b}$ \\
\hline $2 \mathrm{a}$ & 1 & $\mathbf{1 0 0 . 0}$ & & & & & \\
$2 \mathrm{~b}$ & 70 & & $\mathbf{7 4 . 3}$ & 2.9 & & 1.4 & 21.4 \\
$2 \mathrm{c}$ & 9 & & 22.2 & $\mathbf{5 5 . 6}$ & 11.1 & 11.1 & \\
3 & 6 & & & & $\mathbf{6 6 . 7}$ & 33.3 \\
$4 \mathrm{a}$ & 1 & & & & & $\mathbf{1 0 0 . 0}$ \\
\hline
\end{tabular}




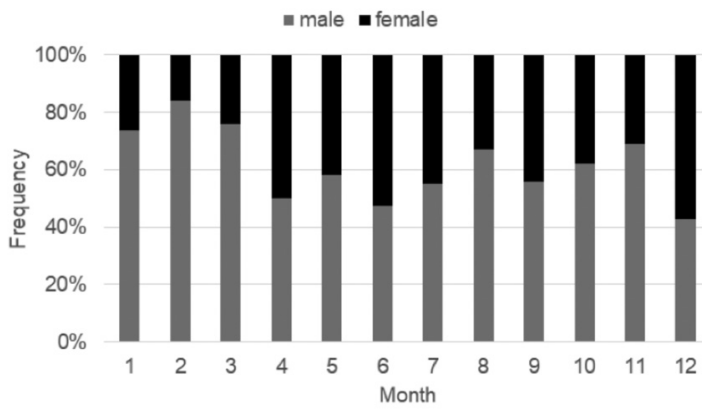

Fig. 5. Monthly sex ratio fluctuations of European hake specimens caught with commercial bottom trawlers along the eastern side of Adriatic Sea, January December 2019.

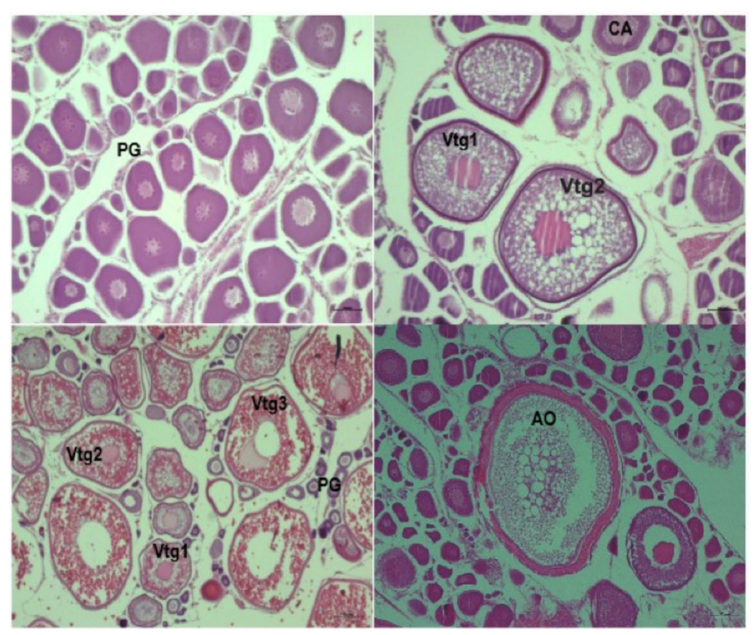

Fig. 6. Images of European hake ovary tissue and oocytes that were observed within it: $P G$ - primary growth oocyte, CA - cortical alveolar, Vtg1 - primary vitellogenic oocyte, Vtg2 - Secondary vitellogenic oocyte, Vtg3 - Teritary vitellogenic oocyte, AO - Atretic oocyte

the collected European hake specimens (15.0 $\mathrm{cm}<\mathrm{TL}<49.0 \mathrm{~cm})$ via commercial bottom trawler was in accordance with the earlier findings obtained through the project "DemMon" (VRGOČ et al., 2004), which also analysed the catches of commercial bottom trawlers in Croatian fishing ground from $2002-2003$. Furthermore, the length distribution of studied fish species was significantly different from its length distribution obtained throughout MEDITS survey (June - July 2019). Within this scientific survey somewhat higher amount of smaller as well as the larger specimens were caught. The reasons for this lie in the fact that according to Croatian law, whole commercial bottom trawl-

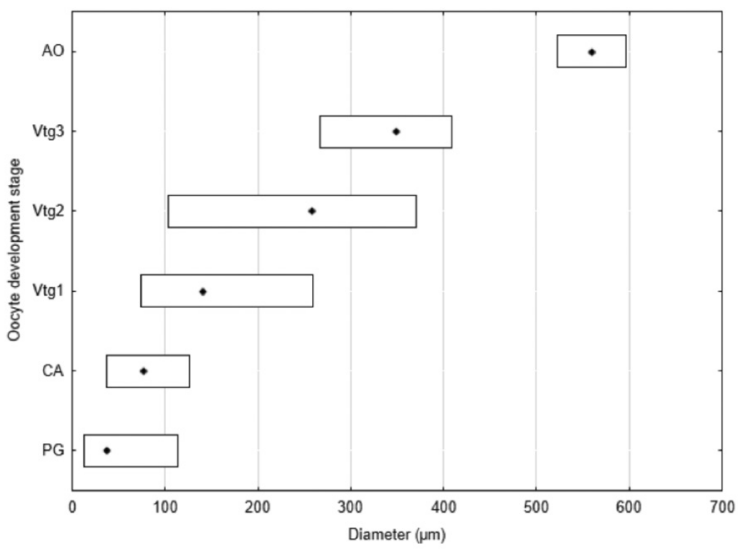

Fig. 7. Measured oocytes diameter ranges for each oocyte development stages observed in European hake ovary histological slides, January - December 2019
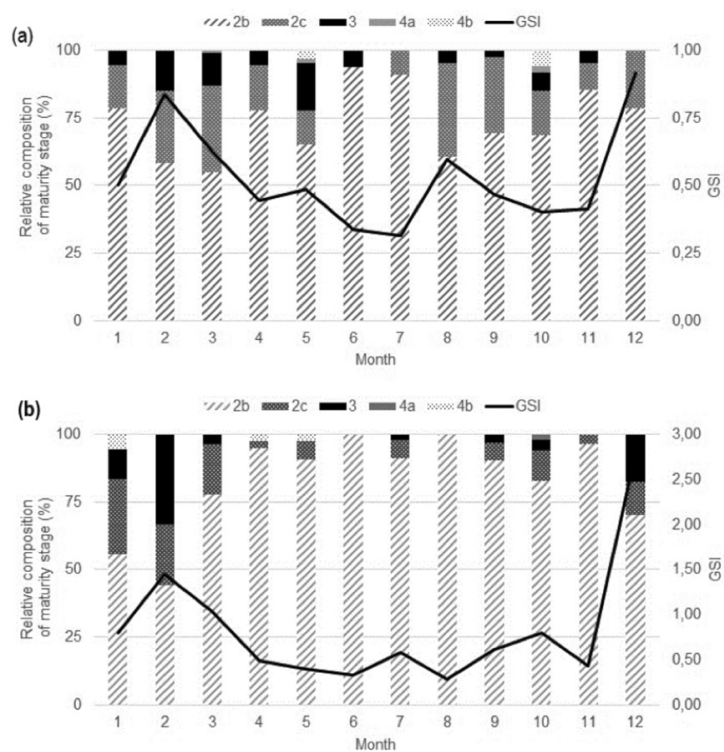

Fig. 8. Monthly oscillation of male (a) and female (b) gonad macroscopically determined maturity stages and mean monthly gonadosomatic index (GSI) of European hake specimens collected on the eastern side of Adriatic Sea from January to December 2019

ing is under spatial-temporal legislation and area of Pomo/Jabuka Pit known as nursery/spawning area of this species is established as Fisheries Restricted Area with a non-take zone (NN, 2016; 2019). Hence, slight differences observed were expected since scientific survey, with smaller mesh size net, try to cover the whole fishing area and areas where commercial vessels are not allowed.

Analysis of the length-weight relationship 


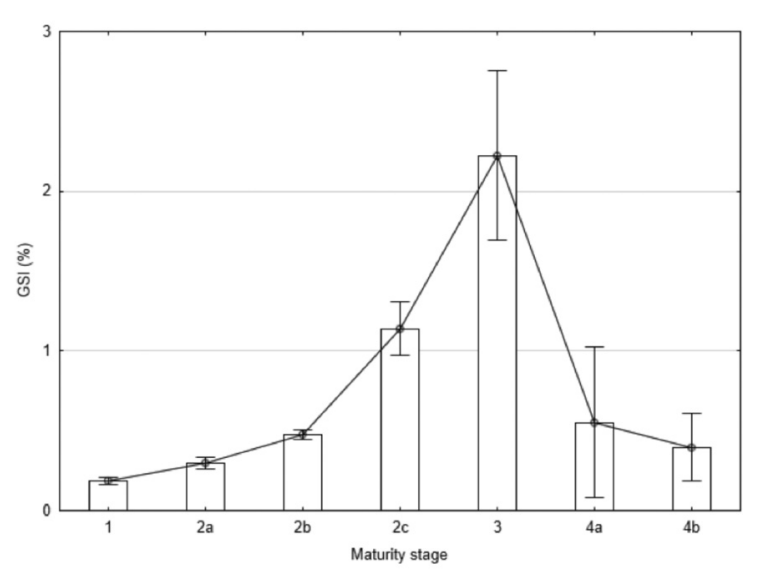

Fig. 9. Oscillation of gonadosomatic index (GSI) regarding the macroscopic maturity stages of European hake specimens collected on the eastern side of Adriatic Sea from January to December 2019
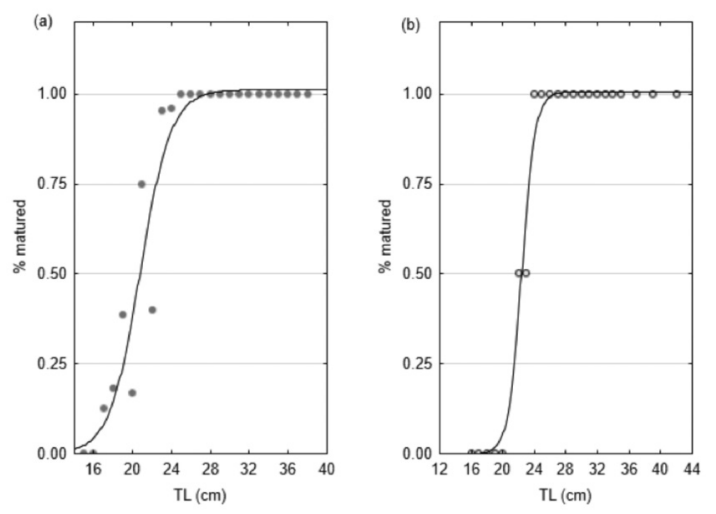

Fig. 10. Maturity ogives of European hake male (a) and female (b) specimens caught within it spawning season (December - February, 2019) with bottom trawlers along the eastern side of Adriatic Sea

of male and female European hake individuals proved to be isometrical (Fig. 3), although according to present data it was obvious that female gained in weight more than males over their life span. Namely, the average body weight of females was higher than males from the same length classes $(25.0 \mathrm{~cm}<\mathrm{TL}<35.0 \mathrm{~cm}$; $\mathrm{W} \widehat{\delta}=155.28 \pm 44.55 \mathrm{~g} ; \quad \mathrm{W} q=182.42 \pm 57.05 \mathrm{~g})$. Overviewing the literature and data regarding the length-weight parameters of European hake inhabiting (VRGOČ et al., 2004; SOYKAN et al., 2015; UZER et al., 2019), minor oscillations between all reported values of allometrical coefficient $(b)$ were noted, but in general results of this study corresponds with the ones previously reported in a review of SARTOR et al. (2017). Those slight allometrical coefficient deviations were expected since length - weight relationship as well as the derived parameters are closely related to geographical areas, sampling strategy, degree of stomach fullness, gonad maturity, sex, size range, health and general fish condition and preservation techniques (FROESE, 2006; JU et al., 2016; TESCH, 1971).

Throughout this study, statistically significant prevalence of male European hake was observed (Figs. 4; 5). Domination of female individuals was pronounced in larger length classes (TL $>31.0 \mathrm{~cm})$ and only during June and December. The greater abundance of males at smaller total body length is well known for this species. Namely, studies of PIÑEIRO and SAÍNZA (2003), HABOUZ et al. (2011) and MELLON-DUVAL et al. (2017) proved that European hake males grow slower than females, which resulted in a greater proportion of females in larger length classes.

Histological observation of ovary tissues confirmed European hake as an indetermined batch spawner with asynchronous oocyte development since all oocytes development stages (Fig. 6) were present at the same time during the season of highest spawning activity (MURUA et al., 2003). These findings were in consistency with previous ones given for the Mediterranean (CARBONARA et al., 2019; RECASENS et al., 2008) and Atlantic (MURUA and MOTOS, 2006) European hake population. The values of the oocytes diameter for different development stages obtained throughout this study (Fig. 7) fitted within their ranges already published by RECASENS et al. (2008) and CARBONARA et al. (2019), while PHILIPS and RAGHEB (2013) reported slightly higher values of ova diameter $(280-840 \mu \mathrm{m})$ for European hakes inhabiting Egyptian Mediterranean waters; most probably due to the fact that they did not measured ova diameter on histological slides of gonad tissues. Microscopical staging due to presence of postovulatory follicles (POF) and atresia (Fig. 6) allowed easier segregation of ovaries that were spent from those that were in the recovery phase. Macroscopic and microscopic scaling of maturity stages show discrepancy that has been noted as well as in the other studies dealing with the same species (CARBON- 


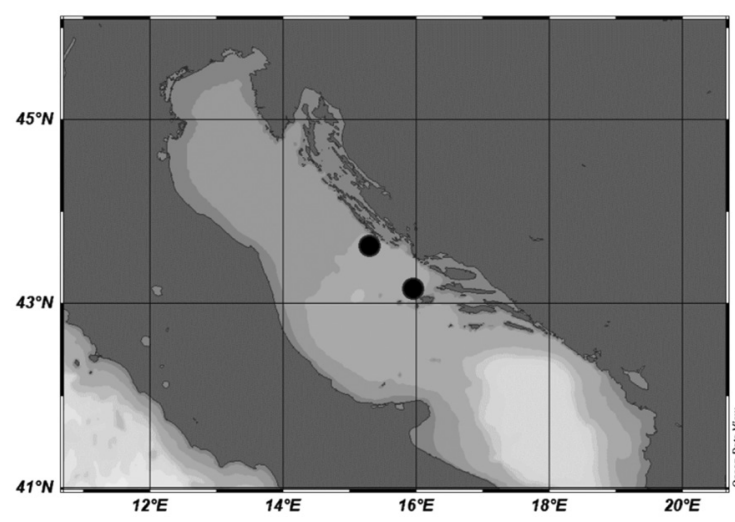

Fig. 11. Sampling stations where European hake eggs were found during the additional ichthyoplankton sampling done along the eastern Adriatic (Croatia) during the MEDITS surveys in July 2019 and July 2020

ARA et al., 2019). Generally, it seems that macroscopic disjunction of spent and recovering maturity stage for European hake is a still difficult task that can be resolved by the implementation of histology as it can detect the presence of POF and atretic oocytes characteristic for spent maturity stage. Misleading results of macroscopic gonad staging might result in incorrect values of length at first maturity, however this is not the case in this study, since in estimation of mentioned length values all stages, beside immature, were included in percent calculation of matured fish. Analysis of GSI values by each maturity stage pointed out that weight of gonads, which was significantly different between almost all observed maturity stages, except between resting and recovery stages, in this study (Fig. 9) and others (CARBONARA et al., 2019; RECASENS et al., 2008), might be one of the parameters that can facilitate macroscopic determination.

According to the values of GSI and proportion of maturity stages over the year in this study (Fig. 8), it was obvious that Adriatic population of European hake mostly spawn during the colder part of the year (December - February) and reached their peak of spawning in December. Furthermore, a slight increase of gonad weights and GSI values along with the appearance of matured stages $(2 \mathrm{c}, 3)$ in wormer part of the year (May- August) suggested that this species tend to actively spawn once again within the same year. This summer spawning activity is also sustained by the fact that during the last two MEDITS surveys (July 2019, July 2020) European hake early life stages, precisely it's eggs, were collected through an additional ichthyoplankton sampling. Namely, on $07^{\text {th }}$ July 2019 (sampling station: $43^{\circ} 37.5^{\circ} \mathrm{N}, 15^{\circ} 18^{\circ} \mathrm{E}$ at $18: 20$ hours) and on $19^{\text {th }}$ July 2020 (sampling station: $43^{\circ} 9.9^{\circ} \mathrm{N}, 15^{\circ} 56.8^{\circ} \mathrm{E}$ at 18:20 hours) two eggs of European hake, genetically confirmed (GenBank accession numbers: MW980055, MW980057), were collected in the open sea area of the middle eastern Adriatic including the area of Jabuka/Pomo pit (Fig. 11). Observed prolonged spawning period, as well as the fact that European hake most probably spawn twice in a year, coincided with previous findings obtained for the same species in the Adriatic (ŽUPANOVIĆ and JARDAS 1989; UNGARO et al., 1993; VRGOČ et al., 2004; CARBONARA et al., 2019).

Furthermore, given that the mature/spent stages were observed throughout the year, although in lower percentages, we can assume that this species spawns throughout the whole year. This is in line with the findings of European hakes inhabiting Mediterranean. Namely, according to review provided by SARTOR et al. (2017; and references within it) Mediterranean population of European hake spawns throughout the whole year or they have one or more peaks of spawning in a year. Obviously, this species has the ability to change its spawning strategy in order to accommodate environmental conditions (like prey availability, changes in sea temperature or salinity etc.) of the geographical area (FERRER-MAZA et al., 2014; CARBONARA et al., 2019). Furthermore, by the extension of spawning season and the fact that this species is a batch spawner, somehow ensured itself with a higher probability to find suitable conditions for larval survival, thereby a higher level of recruitment success as previously reported (JAMES and PITCHFORD, 2003).

In this study, European hake lengths at first maturity for both sexes were rather low (male: $\mathrm{L}_{50}=20.74 \mathrm{~cm}$; female: $\mathrm{L}_{50}=22.38 \mathrm{~cm}$; Fig. 10) but still within the values reported so far for the Adriatic Sea (VRGOČ et al., 2004). Overviewing the literature, the range of the reported lengths 
at first maturity for this investigated species was quite wide going from $21.5 \mathrm{~cm}$ (Cantral Aegean Sea - (SOYKAN et al., 2015)) to $43.0 \mathrm{~cm}$ (Gulf of Lion - ALDEBERT and CARRIES (1989)). Bearing in mind, that majority of the European hakes in the eastern Adriatic Sea are distributed and caught on the continental shelf and/or near its edge as well as the fact that the dominant length classes of those specimens goes from $20.0 \mathrm{~cm}$ to 30.0 $\mathrm{cm}$ obtained vales were expected. Obtained values of length at first maturity in this paper match the best with the values reported by PHILIPS and RAGHEB (2013) and SOYKAN et al. (2015). In both mentioned studies, length-frequency distribution of analysed European hakes was quite similar $(13.0 \mathrm{~cm}<\mathrm{TL}<53.0 \mathrm{~cm}-$ (PHILIPS and RAGHEB, 2013); $9.0 \mathrm{~cm}<$ TL $<45.5 \mathrm{~cm}-$ (SOYKAN et al., 2015)) to one obtained within this study $(15.0 \mathrm{~cm}<\mathrm{TL}<49.0 \mathrm{~cm})$. Additionally, obtained lower values of length at first maturity fits with the findings of DRAZEN and HAEDRICH (2012) who reported that the mentioned value in demersal fish species increase with depth. Namely, European hakes caught below 200 m, as in this study, where feeding intensity according to VELASCO and OLASO (1998) is higher has to reach its first maturity earlier and at smaller length size than the hakes caught in deeper areas of Mediterranean or Atlantic. Obviously, due to a wide length at first maturity range reported for this species within the literature, European hake tends to change its reproduction pattern in the different geographical region. Besides, the observed divergence between the length at first maturity values is often associated with species level of exploitation (LAPPALAINEN et al., 2016) or climate changes. From this study, it was noted that male European hakes reached its maturity at slightly lower length values than its females, but this pattern is general for most teleosts (HELFMAN et al., 1997).

Results of the present study indicated that the Adriatic population of European hake has similar reproductive pattern as their populations distributed along the whole Mediterranean. Observed discrepancies pointed out that European hake spawning phenology is most probably driven by their environmental conditions. Here observed outcomes will, for sure, improve stock assessments and consequently the management of this highly important demersal fish species. Nevertheless, according to TSIKLIRAS and STERGIOU (2014) fish reproductive parameters and its changes in future should be monitor through longer time period in order to understand and elucidate the reasons (phenotypic variability, sampling bias) for their variations that at the end effect assessments of fish species biomass levels and its management.

\section{ACKNOWLEDGEMENTS}

This study was supported throughout the scientific project "Exploration of ecologically sensitive areas with special emphasis on growth, development and protection of commercially important maritime organisms (ESAmar)" founded by Croatian Science Foundation and research project "Data Collection Framework (DCF)" founded by the Ministry of Agriculture of the Republic of Croatia. Thanks to the $\mathrm{PhD}$ Ezgeta-Balić for her help with picture preparation. Finally, many thanks to anonymous reviewers for their useful comments on the manuscript.

\section{REFERENCES}

AAVV. 2017. MEDITS- Handbook, Version N. 9. ed.

ALDEBERT, Y. \& C. CARRIES. 1989. L'exploitation du merlu dans le golfedu Lion. Bulletin de la Société zoologique de France, 114, 15-20.

BROWN-PETERSON, N. J., D. M. WYANSKI, F. SABORIDO-REY, B. J. MACEWICZ \& S. K. LOWERRE-BARBIERI. 2011. A Standardized Termi- nology for Describing Reproductive Development in Fishes. Marine and Coastal Fisheries, 3, 52-70.

CARBONARA, P., C. PORCU, M. DONNALOIA, P. PESCI, L. SION, M. T. SPEDICATO, W. ZUPA, F. VITALE \& M. C. FOLLESA. 2019. The spawning strategy of European hake (Merluccius merluccius, L. 1758) across the Western 
and Central Mediterranean Sea. Fisheries Research, 219: 105333.

CASEY, J. \& J. PERIERO. 1995. Hake: biology, fisheries and markets, in: European Hake (Merluccius Merluccius) in the North-East Atlantic. Chapman and Hall, London, pp. 125-147.

COHEN, D. M., T. INADA, T. LWAMOTO \& N. SCIALABBA. 1990. FAO species catalogue. Vol. 10. Gadiform fishes of the world (Order Gadiformes). An annotated and illustrated catalogue of cods, hakes, grenadiers and other gadiform fishes known to date., FAO Fisheries Synopsis. FAO, Rome, Italy.

DOMÍNGUEZ-PETIT, R., M. KORTA, F. SABORIDOREY, H. MURUA, M. SAINZA \& C. PIÑEIRO. 2008. Changes in size at maturity of European hake Atlantic populations in relation with stock structure and environmental regimes. Journal of Marine Systems, 71: 260-278.

DOMÍNGUEZ-PETIT, R. \& F. SABORIDO-REY. 2010. New bioenergetic perspective of European hake (Merluccius merluccius L.) reproductive ecology. Fisheries Research, 104, 83-88.

DRAZEN, J. C. \& R. L. HAEDRICH. 2012. A continuum of life histories in deep-sea demersal fishes. Deep Sea Research. Part Oceanographic Research Papers, 61, 34-42.

FAO. 2019. GFCM Capture Production 19702018. FishStat. URL http://www.fao.org/ figis/servlet/TabSelector\#lastnodeclicked FAO. 2018. The State of Mediterranean and Black Sea Fisheries. General Fisheries Commission for the Mediterranean, Rome, pp. 1-175.

FAO. 2017. Report of the forty-first session of the General Fisheries Commission for the Mediterranean (GFCM) (GFCM Report No. 41). Rome, Italy.

FERRER-MAZA, D., J. LLORET, M. MUÑOZ, E. FALIEX, S. VILA \& P. SASAL. 2014. Parasitism, condition and reproduction of the European hake (Merluccius merluccius) in the northwestern Mediterranean Sea. ICES Journal of Marine Science, 71: 1088-1099.

FISCHER, W., M. SCHNEIDER \& M. L. BAUCHOT. 1987. Guide Fao d'Identification des Espèces pour les Besoinsde la Pêche Méditerranée et Mer Noire - Zone de Pêche 37. FAO, Rome.
FRATTINI, C. \& P. CASALI. 1998. Distribuzione di Gadiformi in Alto e Medio Adriatico. Biologia Marina Mediterranea, 52: 82-98.

Froese, R. 2006. Cube law, condition factor and weight-length relationships: history, metaanalysis and recommendations. Journal of Applied Ichthyology, 22: 241-253.

GRBEC, B., M. MOROVIĆ, F. MATIĆ, Ž. NINČEVIĆ GLADAN, I. MARASOVIĆ, O. VIDJAK, N. BOJANIĆ, V. ČIKEŠ KEČ, B. ZORICA, G. KUŠPILIĆ \& S. MATIĆ-SKOKO. 2014. Climate regime shifts and multi-decadal variability of the Adriatic Sea pelagic ecosystem. Acta Adriat., 55: 117-126.

HABOUZ, H., L. RECASENS, S. KIFANI, A. MOUKRIM, A. BOUHAIMI \& S. AYOUBI. 2011. Maturity and batch fecundity of the European hake (Merluccius merluccius, Linnaeus, 1758) in the eastern central Atlantic. Scientia Marina, 75.

HELFMAN, G. S, B. B. COLLETTE \& D. E. FACEY. 1997. The diversity of fishes. Blackwell Science, Oxford.

JAMES, A. \& J. PITCHFORD. 2003. The relationship between plankton blooms, the hatching of fish larvae, and recruitment. Ecological Modelling, p. 160.

JU, P.-L., L. YANG, Z.-B. LU, S.-Y. YANG, J.-G. DU, H.-Q. ZHONG, J. CHEN, J.-M. XIAO, M.-R. CHEN \& C.-Y. ZHANG. 2016. Age, growth, mortality and population structure of silver croaker Pennahia argentata (Houttuyn, 1782) and red bigeye Priacanthus macracanthus Cuvier, 1829 in the north-central Taiwan Strait. Journal of Applied Ichthyology, 32: 652-660.

JUKIĆ, S. \& E. ARNERI. 1984. Distribution of hake (Merluccius merluccius L.), Red mullet (Mullus barbatus L.) and pandora (Pagellus erythrinus L.) in the Adriatic Sea. Fisheries Report, FAO, Rome.

JUKIĆ, S. \& C. PICCINETTI. 1981. Quantitative and qualitative characteristics of demersal resources in the Adriatic Sea with some population dynamic estimates. Fisheries Report, FAO, Rome.

JUKIĆ-PELADIĆ, S., N. VRGOČ, V. DADIĆ, S. KRSTULOVIĆ ŠIFNER, C. PICCINETTI \& B. MARČETA. 1999. Spatial and temporal distribution of some demersal fish populations in 
the Adriatic Sea described by GIS technique. Acta Adriat., 40: 55-66.

KORTA, M., D. GARCIA, M. SANTURTÚN, N. GOIKOETXEA, E. ANDONEGI, H. MURUA, P. ALVAREZ, S. CERVIÑO, J. CASTRO \& A. MURILLAS. 2015. European hake (Merluccius merluccius) in the Northeast Atlantic Ocean. pp. $1-37$.

LAPPALAINEN, A., L. SAKS, M. ŠUŠTAR, O. HEIKINHEIMO, K. JÜRGENS, E. KOKKONEN, M. KURKILAHTI, A. VERLIIN \& M. VETEMAA. 2016. Length at maturity as a potential indicator of fishing pressure effects on coastal pikeperch (Sander lucioperca) stocks in the northern Baltic Sea. Fisheries Research, 174: 47-57.

MELLON-DUVAL, C., M. HARMELIN-VIVIEN, L. MÉTRAL, V. LOIZEAU, S. MORTREUX, D. ROOS \& J.M. FROMENTIN. 2017. Trophic ecology of the European hake in the Gulf of Lions, northwestern Mediterranean Sea. Scientia Marina, 81, 7-18.

MURUA, H. 2010. Chapter two - The Biology and Fisheries of European Hake, Merluccius merluccius, in the North-East Atlantic, in: Lesser, M. (Editors), Advances in Marine Biology. Academic Press, pp. 97-154.

MURUA, H., G. KRAUS, F. SABORIDO-REY, P.R. WITTHAMES, A. THORSEN \& S. JUNQUERA. 2003. Procedures to Estimate Fecundity of Marine Fish Species in Relation to their Reproductive Strategy. Journal of Northwest Atlantic Fishery Science, 33, 33-54.

MURUA, H. \& L. MOTOS. 2006. Reproductive strategy and spawning activity of the European hake Merluccius merluccius (L.) in the Bay of Biscay. Journal of Fish Biology, 69, 1288-1303.

NN 68/2016. 2016. Pravilnik o izmjeni pravilnika o prostornom i vremenskom ograničenju obavljanja ribolova na području Jabučke kotline.

NN 82/2019. 2019. Pravilnik o prostornom i vremenskom ograničenju obavljanja gospodarskog ribolova na moru pridnenom povlačnom mrežom - koćom u 2019. godini.

PHILIPS, A. \& E. RAGHEB. 2013. Reproductive Biology of European Hake Merluccius merluccius ( Linnaeus, 1758) in the Egyptian Mediterranean Waters. Egyptian Journal of Aquatic Biology and Fisheries, 17, 37-47.
PICCINETTI, C., N. VRGOČ, B. MARČETA \& C. MANFREDI. 2012. Recent state of demersal resources in the Adriatic Sea, Acta Adriat., Monograph series. Acta Adriat., Split, pp. 1-220.

PIÑEIRO, C. \& M. SAÍNZA. 2003. Age estimation, growth and maturity of the European hake (Merluccius merluccius (Linnaeus, 1758)) from Iberian Atlantic waters. ICES Journal of Marine Science, 60, 1086-1102.

RECASENS, L., V. CHIERICONI \& P. BELCARI. 2008. Spawning pattern and batch fecundity of the European hake (Merluccius merluccius (Linnaeus, 1758)) in the western Mediterranean. Scientia Marina, 72, 721-732.

SARTOR, P., A. MANNINI, R. CARLUCCI, E. MASSARO, S. QUEIROLO, A. SABATINI, G. SCARCELLA \& R. SIMONI. 2017. Sintesi delle conoscenze di biologia, ecologia e pesca delle specie ittiche dei mari italiani/Synthesis of the knowledge on biology, ecology and fishery of the halieutic resources of the Italian seas. Biologia Marina Mediterranea, 24, 607.

SOYKAN, O., A. İLKYAZ, G. METIN \& H. KINACIGIL. 2015. Age, growth and reproduction of European hake (Merluccius merluccius (Linn., 1758)) in the Central Aegean Sea, Turkey. Journal of the Marine Biological Association of the United Kingdom, 95, 829-837.

STECF. 2020. Stock Assessments in the Mediterranean Sea - Adriatic, Ionian and Aegean Seas (No. STECF 20-15). Scientific, Technical and Economic Committee for Fisheries, Luxembourg.

STECF. 2019. Stock Assessments part 2: European fisheries for demersal species in the Adriatic Sea (STECF-19-16).

TESCH, F. W. 1971. Age and growth. In: Methods for Assessment of Fish Production in Fresh Waters. Blackwell Scientific Publications, Oxford.

TSIKLIRAS, A. \& K. STERGIOU. 2014. Size at maturity of Mediterranean marine fishes. Reviews in Fish Biology and Fisheries, 24, 219-268.

UNGARO, N., E. RIZZI \& G. MARANO. 1993. Note sulla biologia e pesca di Merluccius merluccius (L.) nell' Adriatico pugliese. Biologia Marina, Suppl.1: 329-334. 
UZER, U., B. OZTÜRK \& T. YILDIZ. 2019. Age composition, growth, and mortality of European hake Merluccius merluccius (Actinopterygii: Gadiformes: Merlucciidae) from the northern Aegean Sea, Turkey. Acta Ichthyologica et Piscatoria, 49, 109-117.

VELASCO, F. \& I. OLASO. 1998. European hake Merluccius merluccius (L., 1758) feeding in the Cantabrian Sea: seasonal, bathymetric and length variations. Fisheries Research, $38,33-44$.

VRGOČ, N., E. ARNERI, S. JUKIĆ-PELADIĆ, S. KRSTULOVIĆ ŠIFNER, P. MANNINI, B. MARČETA, K. OSMANI, C. PICCINETTI \& N. UNGARO. 2004. Review of current knowledge on shared demersal stocks of the Adriatic Sea. AdriaMed technical Documents No., 12, $91 \mathrm{pp}$.

VRGOČ, N., S. KRSTULOVIĆ ŠIFNER, S. JUKIĆ-
PELADIĆ, M. TONKOVIĆ, P. CETINIĆ, L. GRUBIŠIĆ, A. PALLAORO, V. DADIĆ, M. DESPALATOVIĆ \& I. ISAJLOVIĆ. 2004. Monitoring i gospodarenje demerzalnim resursima uz istočnu obalu Jadrana, Hrvatsko teritorijalno more. Project "DemMon" Report, Institute of Oceanography and Fisheries, Split.

ZAVATARELLI, M., F. RAICICH, D. BREGANT, A. RUSSO \& A. ARTEGIANI. 1998. Climatological biogeochemical characteristics of the Adriatic Sea. Journal of Marine Systems, 18, 227-263.

ŽUPANOVIĆ, Š. \& I. JARDAS. 1989. Fauna i flora Jadrana. Logos, Split.

ŽUPANOVIĆ, Š. \& I. JARDAS. 1987. Fauna i flora Jadrana, Jabučka kotlina, II. Logos, Split.

ŽUPANOVIĆ, Š. \& I. JARDAS. 1986. A contribution to the study of biology and population dynamics of the Adriatic hake, Merrlucius merluccius (L.). Acta Adriat., 27: 97-146.

Received: 9 June 2021

Accepted: 8 September 2021 


\title{
Reproduktivna biologija oslića, Merluccius merluccius (L. 1758), u Jadranskom moru
}

\author{
Barbara ZORICA*, Igor ISAJLOVIĆ, Nedo VRGOČ, Vanja ČIKEŠ KEČ, Damir MEDVEŠEK, \\ Vedran VULETIN, Ivana RADONIĆ, Ratko CVITANIĆ, Ivana LEPEN PLEIĆ i \\ Marija ŠESTANOVIĆ \\ Kontakte-pošta: zorica@izor.hr
}

\begin{abstract}
SAŽETAK
U okviru ovog rada je istražena reproduktivna biologija jadranske populacije oslića, Merluccius merluccius (Linnaeus, 1758). Uzorci istraživane vrste su prikupljeni iz uzoraka lovina ostvarenih komercijalnom pridnenom mrežom koćom s područja istočnog Jadrana (Hrvatsko ribolovno more) jednom mjesečno $(\mathrm{N}=1173)$ tijekom 2019. godine.

Raspon totalnih dužina tijela oslića se kretao između u rasponu od 15,5 cm do 49,5 cm (srednja vrijednost $\pm \mathrm{SD}=27,5 \pm 5,0 \mathrm{~cm}$ ) te je pri većim dužinskim razredima zabilježena dominacija ženki $(\mathrm{TL}>31,0 \mathrm{~cm})$.

Omjer spolova $(\mathrm{m} / \check{\mathrm{z}})$ je iznosio 0,64 ; prevalencija mužjaka je utvrđena tijekom čitave godine izuzev razdoblja mrijesta (prosinac, lipanj) kada je omjer spolova bio u korist ženki. Analizom stadija zrelosti, mase gonada, gonadosomatskog indeksa te histoloških preparata tkiva spolnih žlijezda utvrđeno je da se ova vrsta u Jadranu mrijesti dva puta u jednoj godini; utvrđeno je razdoblje mrijesta od prosinca do veljače, dok je drugo razdoblje mrijesta nešto slabijeg intenziteta utvrđeno početkom ljeta, točnije u lipnju.

Prva spolna zrelost svih analiziranih jedinki oslića je nastupila pri totalnoj dužini tijela od 20,7 cm za mužjake odnosno $22,4 \mathrm{~cm}$ za ženke.
\end{abstract}

Ključne riječi: omjer spolova; sazrijevanje; mriještenje; rani razvojni stadiji; oslić; Sredozemlje 
